\title{
Peer-to-peer psychological contracts in the South African wine industry
}

\begin{tabular}{|c|c|}
\hline \multicolumn{2}{|l|}{$\begin{array}{l}\text { Authors: } \\
\text { Ruth Penfold }{ }^{1} \\
\text { Linda Ronnie }^{1}\end{array}$} \\
\hline \multicolumn{2}{|c|}{$\begin{array}{l}\text { Affiliations: } \\
{ }^{1} \text { Graduate School of } \\
\text { Business, University of Cape } \\
\text { Town, Breakwater Campus, } \\
\text { South Africa }\end{array}$} \\
\hline \multicolumn{2}{|c|}{$\begin{array}{l}\text { Correspondence to: } \\
\text { Linda Ronnie }\end{array}$} \\
\hline \multicolumn{2}{|c|}{$\begin{array}{l}\text { Email: } \\
\text { linda.ronnie@gsb.uct.ac.za }\end{array}$} \\
\hline \multicolumn{2}{|c|}{$\begin{array}{l}\text { Postal address: } \\
\text { Portswood Road, Green Point } \\
\text { 8001, South Africa }\end{array}$} \\
\hline \multicolumn{2}{|c|}{$\begin{array}{l}\text { Dates: } \\
\text { Received: } 09 \text { Mar. } 2015 \\
\text { Accepted: } 10 \text { Sept. } 2015 \\
\text { Published: } 02 \text { Dec. } 2015\end{array}$} \\
\hline \multicolumn{2}{|c|}{$\begin{array}{l}\text { How to cite this article: } \\
\text { Penfold, R., \& Ronnie, L. } \\
\text { (2015). Peer-to-peer } \\
\text { psychological contracts } \\
\text { in the South African } \\
\text { wine industry. SA Journal } \\
\text { of Human Resource } \\
\text { Management/SA Tydskrif vir } \\
\text { Menslikehulpbronbestuur, } \\
\text { 13(1), Art. \#701, } 10 \text { pages. } \\
\text { http://dx.doi.org/10.4102/ } \\
\text { sajhrm.v13i1.701 }\end{array}$} \\
\hline \multicolumn{2}{|c|}{$\begin{array}{l}\text { Note: } \\
\text { This article is partially base } \\
\text { on the Master of Business } \\
\text { Administration Degree the } \\
\text { by Ruth Penfold, supervise } \\
\text { by Dr L. Ronnie at Graduat } \\
\text { School of Business at the } \\
\text { University of Cape Town, } \\
\text { December } 2009 \text {. }\end{array}$} \\
\hline \multicolumn{2}{|c|}{$\begin{array}{l}\text { Copyright: } \\
\text { (C) 2015. The Authors. } \\
\text { Licensee: AOSIS } \\
\text { OpenJournals. This work is } \\
\text { licensed under the Creative } \\
\text { Commons Attribution } \\
\text { License. }\end{array}$} \\
\hline \multicolumn{2}{|l|}{ Read online: } \\
\hline 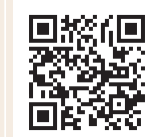 & $\begin{array}{l}\text { Scan this QR } \\
\text { code with your } \\
\text { smart phone or } \\
\text { mobile device } \\
\text { to read online. }\end{array}$ \\
\hline
\end{tabular}

Orientation: Very few studies examine the impact of peer relationships on the psychological contract.

Research purpose: Using the backdrop of wine farm workers in the Western Cape, South Africa, the aim of our study was to explore the nature of peer relationships shaping the psychological contract.

Motivation for the study: The agricultural sector of South Africa, in particular the wine farms in the Western Cape, has undergone radical change in the past decades as a result of labour legislation and changing government structures. It was therefore expected that these changes would influence the psychological contracts held by wine farm workers.

Research approach, design and method: This qualitative study sampled all 24 full-time employees and 2 managers on the Constantia Hills Wine Estate in Cape Town, South Africa. Semi-structured interviews were conducted using the critical incident technique in combination with a series of open questions.

Main findings: Our findings showed support for the existence of peer-to-peer psychological contracts and noted the valuable influence of a suitable conduit individual on the relationship between employees and their employer.

Practical and/or managerial implications: Wine farm workers in South Africa have a strong need to be consulted after a lifetime of having no voice. In addition to ensuring suitable levels of two-way communication, management must understand the inter-peer contract and the nature of the relationships sustaining it.

Contribution: Whilst literature has suggested that management of the psychological contract lies firmly within the domain of the employer, our findings indicated that ensuring harmonious peer-to-peer contracts was also central to good working relationships.

\section{Introduction}

\section{Purpose}

Various studies have been conducted, using different sample groups, investigating the nature and content of psychological contracts as well as the factors impacting on their formation (Bal, Chiaburu \& Diaz, 2011; Conway \& Coyle-Shapiro, 2012; Eckerd, Hill, Boyer, Donohue \& Ward, 2013; Nadin \& Williams, 2012). Most of these studies have been done in developed countries (Hui, Lee \& Rousseau, 2004) with very little focus on the nature and form of employment relationships in the developing world (Hipkin, 2000; Lee \& Mohamed, 2006). Apart from these studies, there appears to be very little evidence of research on the nature of, and factors influencing, the psychological contract amongst poorly skilled and semi-skilled employees of differing levels of literacy and education. Using the backdrop of wine farm workers in the Constantia Valley, South Africa, this article explores the peer relationships shaping the psychological contract of this group of employees.

\section{Literature review}

\section{The South African wine industry}

The agricultural sector of South Africa, in particular the wine farms in the Western Cape, has undergone radical change in the past decade as a result of labour legislation, changing government structures and increasing feminisation of the labour force (Du Toit, Kruger \& Ponte, 2008; McEwan \& Bek, 2006). Historically, the South African wine industry has employed predominantly local, mixed race labourers who have lived and worked on the farm, often under poor conditions, for low wages and in the shadow of a paternalistic culture (Ewert \& Du Toit, 2005; Ewert \& Hamman, 1999; Williams, 2005). Apartheid restricted these workers' 
access to decent education and forced them to be reliant on white farmers for their basic needs such as housing, water and transport. These factors shaped a social identity of dependence, poor self-esteem and powerlessness (Ewert \& Du Toit, 2005).

The paternalistic culture, in conjunction with these factors, resulted in an exchange of employee submission for employer protection. This paternalistic relationship could therefore be seen as the generic psychological contract within the South African wine industry of the past. This type of employment relationship is unique to the agricultural industry and, surprisingly, was sustained by both parties (Du Toit, 1993). This is evidenced by the low levels of unionisation in the agricultural industry compared to that of other industries (Ewert \& Hamman, 1999). This also suggests the possibility that not much has changed in the area of the psychological contract amongst mixed race wine farm workers and their traditionally white male bosses, despite the transformation efforts of the government.

This article contributes to existing literature on the psychological contract through capturing the nuances and influences of relationships within the workplace. It specifically focusses on the nature of peer relationships shaping the psychological contract as well as on the role and impact of those relationships on the formation of the contract. The study promotes an understanding of the unique nature of this contract amongst wine farm workers and establishes key factors that affect and hold sway over it. This brings insight into potential effective people management strategies that would improve employee engagement and enhance business performance.

\section{The psychological contract}

Originally, the psychological contract per se was not defined. Instead, it was seen as the mutual expectations existing between the employee and the employer (Argyris, 1960). It later became recognised as characterising the expectations of both the employees and employers regarding their symbiotic relationship (Hui et al., 2004). Rousseau (1989, p. 123) defines the psychological contract as 'an individual's beliefs regarding the terms and conditions of a reciprocal exchange agreement between the focal person and another party', whilst McLean Parks, Kidder and Gallagher (1998, p. 698) refer to it as 'the idiosyncratic set of reciprocal expectations held by employees concerning their obligations [what they will do for the employer] and their entitlements [what they expect to receive in return]'. A central feature of this contract is the voluntary assent of the individual to make and accept certain promises as he or she understands them (Rousseau, 2011). There is a perception of mutualism and agreement even if the understanding of that agreement is not in fact the same for both parties. This idiosyncrasy of the psychological contract is an important aspect to be aware of as it makes it difficult to manage (Guest, Isaksson \& De Witte, 2010).

The psychological contract has been used to describe the diverse range of contemporary employment relationships (Millward \& Brewerton, 2000; Zhao, Wayne, Glibkowski \& Bravo, 2007), as well as to predict employees' attitudes and well-being (De Cuyper, Rigotti, De Witte \& Mohr, 2008). The key issue emerging from Rousseau's (1989) research is that the psychological contract is dependent upon the belief that a promise, either implicit or explicit, has been made and that a consideration has been made in exchange for it. This binds the two parties to a set of reciprocal obligations. Seeing the psychological contract as merely the expectations of the employee does not capture the fuller, promise-based, reciprocal nature of the psychological contract (CoyleShapiro \& Kessler, 2002; Nadin \& Williams, 2012).

\section{Types of contracts}

There are four main types of contracts that impact organisations and fall under the umbrella of social exchange theory: psychological, normative, implied, and social contracts. They are summarised in Table 1.

The significance of the normative contract in relation to wine farm workers and their individually held psychological contracts is that belief in a shared set of obligations can create social pressures to adhere to those commitments, institutionalising the contract as part of the shared culture of the organisation' (Rousseau, 1995, p. 11). The psychological contract is also perceived as part of the set of normative beliefs that are associated with organisational culture and rewards (Coyle-Shapiro, Shore, Taylor \& Tetrick, 2004; Guest et al., 2010). This has implications for the wine industry as, when a normative contract exists, employees associate themselves in comparable ways with both the organisation and with each other (Rousseau, 1995).

On most South African wine farms, cellar and farm workers will traditionally work in teams that may hold collective beliefs around the organisation's commitments to them and their obligations to the organisation. These beliefs are most likely to stem from the subjective internalisation of the meaning of the paternalism system described earlier. This may, in turn, shape the entire team's behaviour, impacting

TABLE 1: Types of contracts.

\begin{tabular}{lll}
\hline Perspective & Individual & Group \\
\hline Within the contracting parties & $\begin{array}{l}\text { Psychological Contract: Beliefs that individuals hold regarding } \\
\text { promises made, accepted, and relied on between themselves and } \\
\text { another (employee, client, manager, organisation) }\end{array}$ & $\begin{array}{l}\text { Normative Contract: The shared psychological contract that } \\
\text { emerges when members of a social group, organisation, or work } \\
\text { unit hold common beliefs }\end{array}$ \\
$\begin{array}{ll}\text { Implied Contract: Interpretations that third parties (witnesses, } \\
\text { potential employees) make regarding contractual terms }\end{array}$ & $\begin{array}{l}\text { Social Contract: Broad beliefs in obligations associated with a } \\
\text { society's culture (e.g. reliance on handshakes) }\end{array}$ \\
\hline
\end{tabular}

Source: Rousseau, D.M. (1995). Psychological contracts in organizations: Understanding written and unwritten agreements. Thousand Oaks, CA: Sage, p. 9 
the organisation positively or negatively depending on the nature of those beliefs and the degree to which the organisation is perceived to have accepted the normative contract. It would also seem that such normative contracts may impact the organisational culture, thus influencing performance and motivation.

\section{The role of social cues and social influence}

Social cues influence predominantly the psychological contract through social information processing. This is the process whereby employees adopt the attitudes and behaviours of those around them through information obtained from co-workers by direct interaction, observation or both (Conway \& Briner, 2005; Ho \& Levesque, 2005). Rousseau (1995) sees this information from co-workers as the most powerful source of organisational information. Social cues provide messages for contract creation, impart social pressure, and influence how the messages are decoded. Of particular interest in the context of wine farm workers is the role that social cues play in conveying social pressure to conform to the group's interpretation of terms. Reliance on a team to complete activities is a characteristic of the job of wine farm workers. Social pressure is thus likely to be an important factor influencing the shaping of their psychological contract (Guest et al., 2010; Tomprou \& Nikolaou, 2011).

Social influence has been found to occur even when objective information is available (Klein, 1997). Employees are primarily influenced by two sets of social referents. The first is termed 'relational others', that is, those persons with whom an employee has direct contact and social proximity. The second group is 'positionally similar others'. This group may be used as a benchmark for the employee to make judgments around fairness, contract fulfilments and job-specific entitlements (Ho \& Levesque, 2005). The implication is that employees will continually re-assess their psychological contract in order to moderate it relative to the cues of their social referents, making it more similar to theirs over time In addition, having just a general sense of the content of the existing psychological contract amongst some key employees will provide managers with enough information to make reasonable judgments about the expectations of referent others (Ho \& Levesque, 2005). This in turn will aid the understanding and fulfilment of their psychological contract.

In the light of this, the aim of our study was to gain insight into the relationships with others that affect the shaping of the psychological contract of wine farm workers as well as the impact of these relationships on the formation of the contract. In investigating these relationships, the research adds to the existing body of knowledge that sheds light on the multiple contract makers in the formation of the psychological contract, the ways in which employees respond and relate to their organisations, and the role of management in becoming more perceptive in their observation of employee interactions and the social hierarchies that exist in organisations if they wish to understand and manage the psychological contract.

\section{Method The research context}

The study was conducted at the Constantia Hills Wine Estate in the Constantia Valley, South Africa. It is wellestablished as a wine brand both locally and internationally. Constantia Hills has been producing wine since 1689 and the area is considered to be a key producer of quality wines (Van Zyl, 2013). Sixty eight percent of the employees at Constantia Hills have been employed on the farm in excess of 10 years in various roles, with $28 \%$ exceeding the 15 year service mark. This ensured that the impact of the historical employee-employer relationship was captured in the data collected during the study. The profile of the research participants, all full-time employees at Constantia Hills, reflected the composition typically found on wine farms in South Africa during apartheid: the senior management team and owner were white males, while the entire labour force was mixed race. Of the employees, $60 \%$ were male and $40 \%$ female, with $64 \%$ having close relatives also working on the farm. Furthermore, $92 \%$ of all employees lived in the same township, in houses built for them by Constantia Hills. This township was also home to many of the employees of the surrounding wine farms. The farm and packaging departments employed the majority of the staff. Seventy two percent of all the wine farm workers were 36 years of age and older. Thus, most of the employees on Constantia Hills have had work experience within the old paternalistic employment relationship that characterised agriculture in the apartheid era

\section{Data gathering}

All full-time employees and two managers were interviewed. This meant that the entire population of all the farm workers (including cellar staff, packaging staff, general labourers, and farm labourers) was represented and so no issues of representativeness could arise in the data. The management views were sought to gain their overall impression of the existing relationship between themselves and the employees. The employee sample consisted of 19 long-standing and five recently employed permanent staff. Almost half the employee participants had no more than a Grade 7 education with $20 \%$ being illiterate. These indicators are a product of the legacy of apartheid in South Africa and clearly reflect the predominance of the older generation amongst the workers of Constantia Hills. Only one employee had completed her formal schooling, and none had completed tertiary education. This was in stark contrast to the two members of the management team who held tertiary qualifications.

\section{Ethical considerations}

There were two major ethical concerns in the study. The first was that several of the respondents had low levels of literacy. This made them vulnerable to external influence and possible misunderstanding regarding the use of the data they provided. In addition, they traditionally came from 
an employment relationship where the power differential between them and the employer may be considered very large. It was therefore important to provide full assurance of anonymity and give a comprehensive explanation of the nature and scope of the study verbally, in their home language, prior to the data collection. Full assurance of their right to withdraw from the research at any time was also given verbally and their informed consent acquired. Secondly, confidentiality issues around the data needed to be addressed with the organisation prior to the data collection. The names of the respondents and the organisation have therefore all been disguised in the study.

\section{Measures}

Demographic indicators such as age, tenure, job level, race, education and levels of literacy were gathered from the administration officer at Constantia Hills in order to contextualise the case. Semi-structured interviews of between $30 \mathrm{~min}$ to an hour were conducted using the critical incident technique in combination with a series of open questions in order to elicit the perceived obligations of each party, rather than rely on those imposed a priori. The critical incident technique is based on work done by Flanagan (1954, cited in Bryman \& Bell, 2007) and relies on respondents sharing stories, about a specific situation, that are significant ('critical') to them. Using four key questions, research participants were asked to recall an incident(s) where an employee or the organisation went beyond or fell short of what could reasonably be expected of them in their treatment of the other party. Herriot, Manning and Kidd (1997, p. 154) reasoned that 'few employees or managers would be able to provide useful information if asked directly about the implicit obligations governing their employment relationship'.

\section{Data organisation, coding, and analysis}

Creswell (2013) describes a data analysis spiral that was applicable to qualitative studies and which helped to direct the data handling and analysis process. The first step of organising the data involved transcribing it. The consent of the participants to record the interviews was obtained beforehand and the first author also took brief notes during each interview. The advantage of recording the interview was that the researchers could listen to the interviews afterwards to clarify any language uncertainties. This ensured an accurate, unbiased record. The second and third steps in Creswell's (2013) spiral involved the researchers reading through the interviews, making preliminary notes and observations, and then beginning the coding process.

Each transcribed interview was copied into Excel and, using thematic content analysis, the critical incidents were identified along with keywords that were reflective of the themes existing in the literature. Thereafter, the researchers reread the transcripts. This repetitive studying of the data allowed a vast bank of information to be whittled down into smaller chunks of useful information and surfaced the multiple meanings hidden within the data. Themes that we used in the coding of the critical incidents were adapted from previous studies (Herriot et al., 1997; Hipkin, 2000; Lee \& Mohamed, 2006). Emerging themes were discussed by the researchers and revised until consensus was reached. This procedure also improved the validity of the process and contributed to establishing confidence in the findings.

Drawing a clear line between expectations, obligations and promises was difficult. Rousseau and Schalk (2000) have previously raised the issue of the feasibility of this process. The key aspects of the psychological contract were identified by first highlighting all the critical incidents shared, applying the aforementioned themes to the relevant critical incidents, and categorising the incident as an employee or organisational obligation. Thereafter, the number of each critical occurrence was counted and represented as a proportion of the whole. After screening for conformance and criticality as recommended by Butterfield, Borgen, Amundson and Maglio (2005), a total of 302 critical incidents were considered usable. Although there is no established rule in this regard, Flanagan (1954, cited in Bryman \& Bell, 2007) considered saturation to have been reached when no new categories emerged from the data. Our conclusion is that this study met those parameters and the number of critical incidents can be considered sufficient to establish coverage of the psychological contract of Constantia Hills employees. At this point, interpretation, the fourth step of Creswell's (2013) data analysis spiral could take place.

Table 2 reflects the overall number and type of critical incidents regarding the perceived employee obligations, i.e. what the employees considered their obligations to Constantia Hills were and, in turn, what the managers perceived the employees' obligations to be. Seventy three critical incidents were collected from the employee grouping and 29 from the two employer representatives.

Our interviews yielded a number of core themes regarding employee obligations including work, responsibility, relationships and hours. Organisational obligations are shown in Table 3 where the perceptions of the employee and employer about the importance of each of those obligations are presented. There were 172 critical incidents from the employees and 28 from the two managers.

TABLE 2: Employee obligations that emerged as critical incidents.

\begin{tabular}{lccccc}
\hline & \multicolumn{2}{c}{ Employee } & & \multicolumn{2}{c}{ Employer } \\
\cline { 2 - 3 } \cline { 6 - 6 } Critical themes & Number of incidents & $\%$ & & Number of incidents & $\%$ \\
\hline Work & 25 & 34.25 & & 12 & 41.38 \\
Responsibility & 16 & 21.92 & & 11 & 37.93 \\
Relationships & 14 & 19.18 & & 1 & 3.45 \\
Hours & 9 & 12.33 & & 2 & 6.90 \\
Flexibility & 5 & 6.85 & & 0 & 0.00 \\
Honesty/Integrity & 3 & 4.11 & & 1 & 3.45 \\
Loyalty & 1 & 1.37 & & 1 & 3.45 \\
Self-presentation & 0 & 0.00 & & 1 & 3.45 \\
$n$ & 73 & 100 & 29 & 100 \\
\hline
\end{tabular}


TABLE 3: Organisational obligations that emerged as critical incidents.

\begin{tabular}{lccccc}
\hline & \multicolumn{2}{c}{ Employee } & & \multicolumn{2}{c}{ Employer } \\
\cline { 2 - 3 } \cline { 6 - 6 } Critical themes & Number of incidents & $\mathbf{\%}$ & & Number of incidents & $\%$ \\
\hline Environment & 37 & 21.51 & & 2 & 7.14 \\
Relationships & 34 & 19.77 & & 8 & 28.57 \\
Pay & 25 & 14.53 & & 3 & 10.71 \\
Development & 18 & 10.47 & & 7 & 25.00 \\
Fairness & 16 & 9.30 & & 1 & 3.57 \\
Recognition & 13 & 7.56 & & 4 & 14.29 \\
Consultation & 13 & 7.56 & & 3 & 10.71 \\
Benefits & 6 & 3.49 & & 0 & 0.00 \\
Workload & 6 & 3.49 & & 0 & 0.00 \\
Hours & 3 & 1.74 & 0 & 0.00 \\
Security & 1 & 0.58 & & 0 & 0.00 \\
$n$ & 172 & 100 & & 28 & 100 \\
\hline
\end{tabular}

TABLE 4: Explanation of main critical themes.

\begin{tabular}{|c|c|}
\hline Critical themes & Description \\
\hline Work & $\begin{array}{l}\text { To do a good job in terms of quality, quantity and to the } \\
\text { best of your ability }\end{array}$ \\
\hline Responsibility & Taking initiative, owning mistakes and being accountable \\
\hline Relationships & $\begin{array}{l}\text { The norms regarding personal interactions, support at } \\
\text { work, protection against managerial discipline and work } \\
\text { ethic within the team }\end{array}$ \\
\hline Hours & $\begin{array}{l}\text { Leave, length of working day, length of working week, } \\
\text { and breaks }\end{array}$ \\
\hline Environment & Provision of a safe, secure, and congenial workplace \\
\hline Pay & $\begin{array}{l}\text { The actual monthly amount paid as well as the increases } \\
\text { and bonuses granted by Constantia Hills }\end{array}$ \\
\hline Development & $\begin{array}{l}\text { Training, learning and self-improvement through acquiring } \\
\text { new skills and having opportunities for promotion }\end{array}$ \\
\hline
\end{tabular}

The main organisational obligation themes included the environment, relationships, pay and development. These were aspects both parties considered to be the duty and responsibility of Constantia Hills. Both sets of themes are not so very different from those found in similar studies amongst blue-collar workers in South Africa (Hipkin, 2000; Lee \& Mohamed, 2006). However, whilst broad psychological contract themes may exist amongst this class of employee, it can be argued that the unique components of these are likely to differ. Table 4 provides an explanation of the major critical themes identified in the analysis.

The theme of relationships represented the obligation of the employee to build positive peer relationships that were supportive and generated a positive employee-employee psychological contract. It also incorporated obligations such as respect for management and recognition of their support. The importance of 'relationships' was clearly highlighted in the employees' perceptions of both their own obligations $(n=14)$ and that of the organisation $(n=34)$. Given the paucity of research regarding the role of relationships in shaping the psychological contract, the researchers deemed it pertinent to explore the data more explicitly in this regard.

\section{Findings}

Wereport on the findings of our study in three sections: support for the existence of peer-to-peer psychological contracts; the influence of peer-to-peer relationships on the psychological contract; and finally, the influence of a facilitated relationship between the employee and the employer.

\section{Support for the existence of peer-to-peer psychological contracts}

Various types of employee-employee support surfaced in this study that indicated that support and co-operation were important elements in the work lives of all the farm workers at Constantia Hills. Amongst employees, a pervading sense existed that their colleagues were responsible for meeting a certain accepted level of agreed behaviours and obligations, including a minimum expectation surrounding work quality and load. The following quote observing the problem of employees coming to work hung-over on a Monday illustrates these expectations:

'You can't trust those people to do the work properly; some [other employees] have to work harder as a result. You get paid to be here, you should pull your weight as far as I am concerned.' (Barbara, female, employee, 42)

Workers therefore perceived commitment to relationships to have been breached when co-workers did not arrive for work or did not put in a full day's effort. There also seemed to be a tacit agreement amongst workers that they would protect each other from getting into trouble and self-regulate as a team. This sense was validated through the story of the contract worker who 'went to the toilet and slept'. Denzel described his feelings around the incident as follows:

'It is a struggle between us because we feel that everyone must do their duty and that man is not doing his duty. He doesn't earn as much as you but we must all finish the work; it does not matter how much you are paid, you ought to pull your weight.' (Denzel, male, employee, 51)

The incident was never reported even though the permanent employees felt that the contract worker had violated their sense of work ethic. Other inferences to the existence of a self-regulatory system amongst the workers are evidenced in these quotes:

'As we work in the vineyards we regulate each other saying "Look you are being lazy"; we must help each other.' (Mark, male, employee, 43)

'We all work hard at work, support each other, and help each other. We must support each other, work as a group.' (Quinton, male, employee, 36)

'We won't take daily problems to management; we try to sort them out ourselves.' (Shereen, female, employee, 30)

Thus it emerges that the psychological contract in the employment setting is more than managing just the expectations between employee and employer. The evidence points towards an employee-employee psychological contract that, when violated, can impact the productivity, happiness and engagement levels of workers. Conversely, understanding this inter-peer contract, and the nature of the relationships sustaining it, could allow the organisation to realise important changes to the psychological contract. This includes understanding how key individuals within the group create group expectations that are in line with the organisation's expectations of their employees. 


\section{The influence of peer-to-peer relationships on the psychological contract}

It is the researchers' belief that the organisational environment provides the context in which the other content elements of the contract are experienced. As such, the context of 'family', implying high commitment, high integration and relational interdependency, can realistically be considered an important shaper of the psychological contract at Constantia Hills. Furthermore, the relationships between colleagues were long-standing with the majority of workers at Constantia Hills having been employed by the organisation for a lengthy period and $90 \%$ of employees living next door to each other. Rousseau (2001) found that the extent to which individuals have formed stable psychological contracts is related to length of employment and this influences their understanding of the employment relationship. It is her assertion that veterans have psychological contracts that are more difficult to alter. The impact of these long-standing relationships and close domestic proximity is thus likely to be entrenched in the psychological contract and be more resistant to change than in organisations where average tenure is much shorter. The following quote supports this theory:

'You can see that some of the workers stick to themselves, they cannot adjust to the system, but it goes much better with the new generation. They fit in easier than the old generation.' (John, male, employee, 28)

The high proportion of family living together and working together, as well as the social community in which employees lived, directly impacted the levels of engagement and productivity of employees based on their observation and understanding of the organisation's treatment of their social referents and family, as this comment from employee Freda highlights:

'The thing that is unhealthy is that if one member of the family is unhappy it gets discussed at home and they form their own perception; and maybe you will work here with a very brilliant worker but he is unhappy about something that happened to his sister's husband that also works here.' (Freda, female, employee, 44)

Employees are primarily influenced by two sets of social referents. The first is termed 'relational others', that is, those with whom there is direct contact and strong social proximity; the second group is 'positionally similar others' in the informal social structure (Ho \& Levesque, 2005, p. 276). Pay, recognition and perceptions of fairness were found to be particularly influenced by referent others and social setting. Pay was moderated by the knowledge of positionally similar referents' wages at neighbouring farms whose employees also resided in the same residential area. For those whose referent others earned less, positive feelings towards the organisation's fulfilment of the financial aspect of the psychological contract was experienced. However, those who appeared to earn less than their referent others were less positive and more inclined to raise their expectations in the light of their observations. Thus relationships external to the organisation can also be seen as important mediators of the expectations of employees regarding the organisation's specific obligations.

Perceptions of fairness or procedural justice had a significant influence on motivation for those working in a large team where each member's contribution was vital to achieving the team goals and performance. The following quote underscores this:

'They are not stupid, they know, they see it. It just takes one incident and then everything is not good. For instance, there is a permanent [employee] in the vineyards that is never at work on a Monday so he just doesn't get paid but he should actually be dealt with but he hasn't been. This sends out a massive message to the others. It just demotivates you, "Why am I here if the work that you do doesn't get seen?"' (Fred, male, employee, 53)

Where organisational support was perceived to be lacking, there was a suspension of communication with the organisation and a shift to increased peer communication. As Noel (male, employee, 26) notes, 'they did nothing about this. We don't complain anymore because nothing happens'. When employees stop communicating with the organisation, the psychological contract is negatively affected over time as employees are left to fill in the missing information about the intents and purposes of the organisations' future actions and obligations for themselves (Bal et al., 2011; Coyle-Shapiro \& Kessler, 2002). Much of this information is then supplied by social referents whose information may be inaccurate and biased, leading to the entrenchment of a 'group' psychological contract that is not understood by management but is embraced by the work team. This group contract would incorporate the employeeemployee obligations of the inter-peer psychological contract expounded earlier as well as the perceptions regarding organisational and employee obligations. Once formed, the psychological contract resists change making it critical that the organisation take responsibility for creating an environment where concerns are heard and acted upon, thus ensuring consistent, accurate, two-way communication and healthy relationships all round.

The large team nature of the work environment at Constantia Hills influenced the degree to which certain aspects of the psychological contract were embraced by individuals within the team, as well as the degree to which the employer could effectively fulfil his or her obligation of recognition. The ability to foster responsibility was particularly hindered by these large group interactions as members were shielded by others, or conversely gained no recognition for individual efforts as a blanket approach of 'what I do for one I must do for the other' often had to be adopted to ensure perceptions of fairness were maintained. Equally so, the employer acknowledged that high individual responsibility within a large group was probably an unrealistic expectation as Jack, stated:

'You can't make one guy responsible in a group of twenty. It is impossible because they will never take responsibility like that.' (Jack, male, manager, 35) 
Furthermore, the degree of acceptance within the group of one member being elevated to a superior position was strongly mediated by the length of the relationships in the group, levels of trust amongst the group members, perceptions of relative worth and contribution and the procedural justice of such an appointment:

'You see they [the organisation] come and look and see if we finished doing our work as a team, but they don't see what that one [has done] and what I have done.' (Sara, female, employee, 49)

Likewise Tammy felt unrecognised through the 'employee of the year' competition, as this account revealed:

'Last year we all worked together and then the boss came to say he is going to give a certificate to the one who works hard, and then there was some unhappiness because we felt that we all work hard, so why should just one person get a prize?' (Tammy, female, employee, 32)

These accounts suggest that monetary reward in terms of good pay rises was a general expectation that Constantia Hills seemed to exceed. However, more subtle issues - such as a person's sense of the value they contributed, a comparative sense of how hard they worked - influenced the degree to which employees seemed to feel that Constantia Hills was fair with regards to the manner in which it gave recognition. Here, how much, to whom and for what reason recognition was given was important. Tammy's feelings emphasised that the organisation had to be sensitive about using 'employee of the year' type competitions to motivate and raise performance standards. It was perceived as demotivating for those employees who had put in a lot of effort but did not win and so did not have their contribution recognised. This was especially felt in departments where performance was contingent on teamwork. This feeling pervaded despite these competitions being voted on by fellow employees. Both maintaining high levels of procedural justice as well as structuring smaller work groups appeared to be key tools in ensuring trustful relationships between colleagues as well as with the organisation:

'I would just like to have smaller teams ... it changes everything ... you can have more of a conversation.' (Lydia, female, employee, 34)

This, in turn, allows for more open communication within these two sets of relationships, leading to greater opportunity to maintain a positive contract and/or bring about desired change to that contract. Guest and Conway (2002) support this idea, having found that job related communication had a steady positive relationship with explicit contracts that in turn increase fairness and trust. Thus, the level of expectation for pay, increases and benefits is still likely to be strongly influenced by a positionally similar referent. Concomitantly, greater trust and communication amongst peers may lead to a strengthening of the inter-employee psychological contract presented earlier. This could assist in entrenching desired aspects such as mutual responsibility and high levels of workmanship as well as slowly creating a forum for the team acknowledgement of high performing members.

\section{Social hierarchies and peer relationships}

Beyond the supervisor versus subordinate dynamic, an array of inter-employee relationships in the form of social hierarchies emerged in this study, including permanent versus contract employee relationships, men versus women, young versus old employees. The following extracts highlight these hierarchies:

'There is a system down there of domination that you don't see. The permanent worker will sit and eat her lunch but the contractors are not allowed to go into the [eating area] and eat with the permanents.' (Rod, male, employee, 32)

'The women just take orders, they really are the bottom of the rung ... you still have, "the men are better than the women." (Kate, female, employee, 47)

'The older ones are more dominant. There is a lot of "I have been here for 25 years; you are new, sit back please". There are little gangs; it is like a "mafia".' (Sara, female, employee, 23)

These social hierarchies influenced the nature of the relationships amongst employees on the farm and thus also the behaviour and views of referent others used by the farm workers to assess different situations. In turn, the expectations of employees regarding elements of the psychological contract were moderated. In the case of contract employees, they were perceived to be inferior and lazy, definitely occupying a lower social rung on the farm in the minds of the permanent employees. The relationship was one of superiority and entitlement. The permanent staff appeared to use the concessions granted to contract employees as a measuring stick against which to assess their own entitlements, which involved more benefits than the contractors as they (the permanent employees) perceived themselves to be reciprocating with a greater work ethic expressed as doing the work properly, and to the best of their ability - than the contractors. It was also the researchers' sense that increasingly integrating contract workers into the norms and rituals of Constantia Hills may have been perceived by permanent employees as a breach of their psychological contract, which included the expectation of employment security. An example of this was the unwillingness of permanent farm workers to give their old rain clothes to the contract workers as described in this story told by Doreen:

'Work clothes are given every year to the permanent farm people. Jack asked them to bring their old rain clothes back so that he could give them to the contract workers. Many refused.' (Doreen, female, employee, 51)

This action highlighted permanent workers' reluctance to allow their superior relationship with the contractors to be diminished by this group assuming the same entitlements as them.

Reaction to social pressure within these hierarchies appeared to be mediated by the value the employee placed on a particular exchange. In one instance Marie, placed high value on learning and having the ability to take on a greater variety 
of tasks. As such, she chose to offer her trustworthiness and work ethic as a reciprocal commitment in return for training, rather than adhere to the team norm for work that is, she exceeded the norm in terms of quantity and open communication with the organisation. This can be seen by her comment:

'[My employer $]$ trusts me. I don't listen to other people. I go and tell him when my work is finished and then he sends me to do more work elsewhere.' (Marie, female, employee, 32)

It would appear from this that whilst social cues and peer pressure are usually factors that shape the psychological contract of the workers, when a reciprocal obligation exists between an employee and the employer around an issue of great value to that employee, they are more likely to disregard the influence of social referents. This supports Aggarwal, Datta and Bhargava's (2007) claim that employees filter information according to their personal goals and values and may explain some of the more idiosyncratic elements of the psychological contract.

\section{The influence of a facilitated relationship between employee and employer}

It was apparent that certain aspects such as environment, development and recognition present particularly powerful elements that, if fulfilled by the employer, could bring about desired changes in the attitudes of employees towards responsibility and workmanship. This suggests that an important factor in maintaining the psychological contract, or even re-negotiating it over time, is the degree to which specific, highly salient elements of the contract are satisfactorily fulfilled. The question then arises as to how the employer is to ensure that his or her perceptions of the obligations existent between the organisation and the employee are congruent with those of the employee? Having a conduit to the employees, in the form of Doreen, a longserving and senior employee, was identified as critical to understanding how the employees understood the terms of the psychological contract and how that understanding changed or remained constant:

'It is very important that you have a strong leader who can open up to you, like Doreen for instance. They will talk to Doreen and that information will come to you; it might be a week later but it will get to you. It is important that you get that information to keep your working force up otherwise nothing will happen out there.' (Dirk, male, manager, 39)

This single individual relationship impacted both groups party to the psychological contract as the employees identified with her as one of them: 'they see me as their representative' (Doreen, female, employee, 51). In this case Doreen represented someone who had the same background as the employees and so shared an understanding of their cognitive styles and concerns, but also corresponded closely enough with management in terms of her cognitive style to act as a conduit between the two. That Doreen is very involved in all the employee committees and forums on the farm is likely to be a significant reason that so few stories of contract violation in the past few years were experienced by the employees. The quality of information to the employee and from the employee had improved as a result of this conduit relationship; this last being important in the maintenance of the psychological contract (Guest et al., 2010; Rousseau, 2001; Tomprou \& Nikolaou, 2011).

\section{Discussion}

To a large extent, most of the perceptions of employees at Constantia Hills were formed by the negative impact of the paternalistic system of the past. These past behaviours shaped their mental models and so today their psychological contract tends to resist change, making developing a culture of responsibility and empowerment potentially difficult and slow. The role of relationships immediately gains greater significance than being only a content element of the psychological contract when the idea of a peer-to-peer psychological contract is entertained. Constantia Hills' workforce reflected the traditional composition found on most wine farms in South Africa. Age, organisational tenure and education all have a unique influence on the existing psychological contract and suggest that difficulties may arise in changing the contract of long-time employees as the farm continues to transform itself into a model more empowered than the historical paternalistic system. The existence of a large proportion of poorly skilled contract labourers seemed to have a moderating impact on the psychological contract of the existing employees and so should not be overlooked as an important factor influencing the formation of the psychological contract of the permanent staff at Constantia Hills.

Evidence of an employee-employee psychological contract was found in this study and suggests the importance of management understanding social hierarchies and peer relationships. Having a conduit through one significant leader amongst peers may be a highly effective way of ensuring that messages and obligations are both clearly and consistently communicated. Where this person has similar cognitive styles of thinking to management with an understanding of the cognitive styles of employees, the chance for incongruence in expectations is greatly reduced. Constant, clear communication that does not conflict with actions and reveals the intent of management is critical to the maintenance of the psychological contract. Employees at Constantia Hills have a high need to be consulted after a lifetime of having no 'voice' and thus two-way communication is important.

The contract maker is definitely a very powerful factor shaping the psychological contract of employees and has the greatest potential to bring about changes in their current psychological contract. This is due to the personalised communication and ability to build trust and invoke ownership and commitment through relationship. Thus working in smaller groups could greatly help to maintain the psychological contract. Suazo, Turnley and Mai-Dalton (2008) found that the more similar the cognitive schemata of the contract maker and the person with whom he or she 
interacts, the more likely that the psychological contract obligations will be understood in a similar manner. This similarity provides a common frame of reference that promotes the mutual understanding of the terms and conditions of the psychological contract.

This study is particularly significant given recent and ongoing events within the farming communities of the Western Cape in South Africa. Tensions between farmers and their workforce resulted in the death of three workers and millions of rands of insurance claims (Davis, 2013). Although Constantia Hills was unaffected by the farm workers' industrial action and has made tremendous strides in attempting to bring about more equitable working conditions for their employees, they may not always remain immune unless they attend to the psychological contracts of their employees. However, whilst literature has suggested that management of the psychological contract lies firmly within the domain of the employer (Coyle-Shapiro et al., 2004; Nadin \& Williams, 2012), our findings indicate that ensuring harmonious peer-to-peer contracts is also central to good working relationships, thus creating a more productive experience for all. This is particularly pertinent within the volatile South African agricultural sector where the historical imbalances created by the apartheid past need urgent redress.

\section{Conclusion}

This study provides an encouraging insight into the role of the relationships shaping the psychological contract of wine farm workers, an area relatively under-explored to date. The findings suggest that inter-peer relationships play a meaningful role in influencing this contract. Wine farm workers in South Africa are in the process of attempting to restructure and renegotiate their employment relationships. This empirical study highlights the importance of understanding the needs and expectations of this group of employees. Given that the wine industry is a people-intensive one, the findings reiterate the need for farm management to create an environment that generates trust, builds self-worth, and enables ownership.

\section{Future research and limitations}

A limitation to this study relates to the context of the investigation. This study focuses on a single, privately owned wine farm in the Constantia Valley and thus findings cannot be generalised beyond this particular organisation to a broader population. A further limitation of the investigation may be the replicability of the study. The South African wine industry is going through a period of legislative change and transformation that may result in different findings emerging from the same organisation at some point in the future.

There is scope for further research around the psychological contract of contracting labourers on wine farms. This study focused on permanent employees only. However, many of the contract employees on Constantia Hills had been employed for 7-8 years, raising the question of whether they have, over time, adopted the psychological contracts characteristic of permanent employees. The impact of contract employees on the expectations and entitlements that permanent employees perceive is a further topic that has yet to be explored.

In the context of South Africa, additional research is needed on the role of apartheid in the formation of the psychological contract across racial groups at various employment levels, including previously advantaged as well as disadvantaged groups. Examining generational differences in the psychological contract may well aid this. Finally, more indepth research on the impact of different management styles and the personality of the contract maker on the psychological contract would enable organisations to develop managers able to elicit positive employee behaviours through managing psychological contract formation and continuance.

\section{Acknowledgements Competing interests}

The authors declare that they have no financial or personal relationships which may have inappropriately influenced them in writing this article.

\section{Authors' contributions}

R.P. (University of Cape Town) was the main researcher and was responsible for conducting fieldwork, as well as writing up the research. L.R. (University of Cape Town) supervised the research and made conceptual contributions to the study.

\section{References}

Aggarwal, U., Datta, S., \& Bhargava, S. (2007). The relationship between human resource practices, psychological contract and employee engagement: Implications for managing talent. IIMB Management Review, 19(3), 313-325.

Argyris, C. (1960). Understanding organisational behaviour. Homewood, IL: Dorsey Press.

Bal, P.M., Chiaburu, D.S., \& Diaz, I. (2011). Does psychological contract breach decrease proactive behaviors? The moderating effect of emotion regulation. decrease proactive behaviors? The moderating effect of emotion regulation.
Group and Organization Management, 36(6), 722-758. http://dx.doi. Group and Organization Man
org/10.1177/1059601111423532

Bryman, A., \& Bell, E. (2007). Business research methods. New York, NY: Oxford University Press.

Butterfield, L.D., Borgen, W.A., Amundson, N.E., \& Maglio, A.-S.T. (2005). Fifty years of the critical incident technique: 1954-2004 and beyond. Qualitative Research, 5(4), 475-497. http://dx.doi.org/10.1177/1468794105056924

Conway, N., \& Briner, R.B. (2005). Understanding psychological contracts at work A critical evaluation of theory and research. Oxford: Oxford University Press.

Conway, N., \& Coyle-Shapiro, J.A.-M. (2012). The reciprocal relationship between psychological contract fulfilment and employee performance and the moderating role of perceived organizational support and tenure. Journal of Occupational and Organizational Psychology, 85(2), 277-299. http://dx.doi.org/10.1111/j.20448325.2011.02033.x

Coyle-Shapiro, J.A.-M., \& Kessler, I. (2002). Exploring reciprocity through the lens of the psychological contract: Employee and employer perspectives. Journal of Work and Organizational Psychology, 11(1), 69-86.

Coyle-Shapiro, J.A.-M., Shore, L.M., Taylor, M.S., \& Tetrick, L.E. (Eds.). (2004). The employment relationship: Examining contextual and psychological perspectives. Oxford: Oxford University Press.

Creswell, J.W. (2013). Qualitative inquiry and research design: Choosing among five approaches. Thousand Oaks, CA: Sage Publications.

Davis, R. (2013, October 28). Western Cape farm strikes: One year on, still a political football. Daily Maverick. Retrieved December 16, 2013, from http://www. dailymaverick.co.za/article/2013-10-28-western-cape-farm-strikes-one-year-on dailymaverick.co.za/article/2013-10-28-western-cape-farm-strikes-one-year-o -still-a-political-football/\#.UptI5WthiSM

De Cuyper, N., Rigotti, T., De Witte, H., \& Mohr, G. (2008). Balancing psychological contracts: Validation of a typology International Journal of Human Resource Management, 19(4), 543-561. http://dx.doi.org/10.1080/09585190801953590 
Du Toit, A. (1993). The micro-politics of paternalism: Discourses on management and resistance on South African fruit and wine farms. Journal of South African Studies, 19(2), 314-336. http://dx.doi.org/10.1080/03057079308708362

Du Toit, A., Kruger, S., \& Ponte, S. (2008). Deracializing exploitation? 'Black economic empowerment' in the South African wine industry. Journal of Agrarian Change, 8(1), 6-32. http://dx.doi.org/10.1111/j.1471-0366.2007.00161.x

Eckerd, S., Hill, J., Boyer, K.K., Donohue, K., \& Ward, P.T. (2013). The relative impact of attribute, severity, and timing of psychological contract breach on behavioral and attitudinal outcomes. Journal of Operations Management, 31(7), 567-578. http:// dx.doi.org/10.1016/j.jom.2013.06.003

Ewert, J., \& Du Toit, A. (2005). A deepening divide in the countryside: Restructuring and rural livelihoods in the South African wine industry. Journal of Souther African Studies, 31(2), 315-332. http://dx.doi.org/10.1080/03057070500109524

Ewert, J., \& Hamman, J. (1999). Why paternalism survives: Globalization, democratization and labour on South African wine farms. Sociologia Ruralis, 39(2), 202-222. http://dx.doi.org/10.1111/1467-9523.00102

Guest, D.E., \& Conway, N. (2002). Communicating the psychological contract: An employer perspective. Human Resource Management Journal, 12(2), 22-38. $\mathrm{http}: / /$ dx.doi.org/10.1111/j.1748-8583.2002.tb00062.x

Guest, D.E., Isaksson, K., \& De Witte, H. (Eds.). (2010). Employment contracts, psychological contracts, and employee well-being: An international study. Oxford: Oxford University Press.

Herriot, P., Manning, W.E.G., \& Kidd, J.M. (1997). The content of the psychological contract. British Journal of Management, 8(2), 151-162. http://dx.doi. org/10.1111/1467-8551.0047

Hipkin, I. (2000). Managerial and worker perceptions of the workplace: A case of South African agriculture. South African Journal of Labour Relations, 24(2), 4-22.

Ho, V.T., \& Levesque, L.L. (2005). With a little help from my friends (and substitutes): Social referents and influence in psychological contract fulfillment. Organization Science, 16(3), 275-289.

Hui, C., Lee, C., \& Rousseau, D. (2004). Psychological contract and organizationa citizenship behavior in China: Investigating generalisability and instrumentality. Journal of Applied Psychology, 89(2), 311-321. PMID: 15065977.

Klein, W.M. (1997). Objective standards are not enough: Affective, self-evaluative, and behavioral responses to social comparison information. Journal of Personality and Social Psychology, 72(4), 763-774. PMID: 9108694, http://dx.doi. org/10.1037/0022-3514.72.4.763

Lee, G.J., \& Mohamed, Y. (2006). Perceptions of workplace issues among blue-collar workers in South Africa's Gauteng province. South African Journal of Psychology, 36(1), 45-62. http://dx.doi.org/10.1177/008124630603600104

McEwan, C., \& Bek, D. (2006). (Re)politicizing empowerment: Lessons from the South African wine industry. Geoforum, 37(6), 1021-1034. http://dx.doi.org/10.1016/j. geoforum.2006.06.004
McLean Parks, J., Kidder, D., \& Gallagher, D.G. (1998). Fitting square pegs into round holes: Mapping the domain of contingent work arrangements onto the psychological contract. Journal of Organizational Behavior, 19(S1), 697-730. http://dx.doi.org/10.1002/(SICI)1099-1379(1998)19:1+<697::AIDJOB974>3.0.CO;2-I

Millward, L.J., \& Brewerton, P.M. (2000). Psychological contracts: Employee relations for the twenty-first century? International Review of Industrial and Organizational Psychology, 15, 1-61.

Nadin, S.J., \& Williams, C.C. (2012). Psychological contract violation beyond an employees' perspective: The perspective of employers. Employee Relations, 34(2), 110-125. http://dx.doi.org/10.1108/01425451211191841

Penfold, R.F. (2009). The psychological contract: Workers at a Constantia Valley wine farm. Unpublished master's thesis, University of Cape Town, Cape Town, South Africa.

Rousseau, D.M. (1989). Psychological and implied contracts in organizations. Employee Responsibilities and Rights Journal, 2(2), 121-139. http://dx.doi.org/10.1007/ BF01384942

Rousseau, D.M. (1995). Psychological contracts in organizations: Understanding written and unwritten agreements. Thousand Oaks, CA: Sage.

Rousseau, D.M. (2001). Schema, promise, and mutuality: The building blocks of the psychological contract. Journal of Occupational and Organizational Psychology, 74(4), 511-541. http://dx.doi.org/10.1348/096317901167505

Rousseau, D.M. (2011). The individual-organization relationship: The psychological contract. In S. Zedeck (Ed.), APA Handbook of industrial and organizational psychology (pp. 191-220). Washington, DC: American Psychological Association.

Rousseau, D.M., \& Schalk, R. (Eds.). (2000). Psychological contracts in employment: Cross-national perspectives. Thousand Oaks, CA: Sage.

Suazo, M.M., Turnley, W.H., \& Mai-Dalton, R.R. (2008). Characteristics of the supervisor-subordinate relationship as predictors of psychological contract breach. Journal of Managerial Issues, 20(3), 295-312.

Tomprou, M., \& Nikolaou, I. (2011). A model of psychological contract creation upon organizational entry. Career Development International, 16(4), 342-363. http:// dx.doi.org/10.1108/13620431111158779

Van Zyl, D.J. (2013). Three centuries of Cape wine. Retrieved from http://www.wosa. co.za/sa/history_3centuries.php

Williams, G. (2005). Black economic empowerment in the South African wine industry. Journal of Agrarian Change, 5(4), 476-504. http://dx.doi.org/10.1111/j.1471 $-0366.2005 .00109 . x$

Zhao, Z., Wayne, S.J., Glibkowski, B.C., \& Bravo, J. (2007). The impact of psychological contract breach on work-related outcomes: A meta-analysis. Personnel Psychology, 60(3), 647-680. http://dx.doi.org/10.1111/j.1744 -6570.2007.00087.x 